\title{
Inflammatory stress and idiosyncratic drugs hepatotoxicity in rabbit
}

\author{
H. T. Mohamed \\ Coll. of Vet. Med. /Unive. of Basra
}

Abstract

Back ground: idiosyncratic drug hepatotoxicity is none or time related, unpredictable, occurs infrequently and can be fatal. It was proposed that inflammatory or oxidative stress occurs randomly in patients even after asymptomatic incidence can precipitate drug hepatotoxicity.

Aim: To measure hepatotoxicity of diclofenac in rabbit serum following the incidence of inflammatory stress by lipopolysaccharide (LPS) and correlate this to various stress parameters as Malondialdehyed (MDA).

Method: 24 rabbits were divided into four groups (6 each) according to type of treatment.

Group 1: control (received normal saline).

Group 2 received diclofenac sod. (5mg/kg, orally 3times daily for three days).

Group 3: received lipopolysaccharide $(150 \mu \mathrm{g} / \mathrm{kg}$, i.v, 24 hours before killing.

Group 4: received diclofenac sod. + Lipopolysaccharide $(5 \mathrm{mg} / \mathrm{kg}$ orally $+150 \mu \mathrm{g} / \mathrm{kg}$, i.v 24 hours before killing).

Then for each animal were measure, liver M D A, liver enzymes.

Conclusion: LPS potentiated the hepatotoxic effect of diclofenac sod. The effect is mediated by oxidative and inflammatory reactions as demonstrated by increase in liver tissue M D A.

\section{Introduction}

Drug induce hepatotoxicity is an important human problem.In United Kingdom recent study found that adverse drug reaction responsible for more than $6 \%$ of hospital admission and the mortality rate is approximately $2 \%$ (1),and it is expected that the real incidence might be greater than estimated by current method (2), (3)). Withdrawal of some efficacious drugs due to idiosyncratic hepatotoxicity leads to deficits in treatment, an example of this is felbamate (4).which was effective in treats sever cases of epilepsy. It's used markedly reduce because of its association with a plastic anemia and hepatotoxicity in some patients (5).Idiosyncratic adverse drug reaction that target the liver are common cause of acute liver failer in the united states according for more than $10 \%$ of cases , the results of 5 years prospective study indicate that many dietary supplement and drugs with different pharmacological targets are associated with idiosyncratic hepatotoxicity.(6).Andrade et al 2005 (7) cited that anti - infective, and musculo skeletal and gastro intestine tract drugs are the main group of drugs, which can cause hepatotoxicity.

\section{Material and Methods}

a. chemicals: Thiobarbituric acid (BDH ,chemical ,Ltd. Pool, England.)Trichloro acetic acid ( $\mathrm{T} \mathrm{C} \mathrm{A)} \mathrm{from} \mathrm{Thomas} \mathrm{Baker,}$ Ltd, India .Lipopolysacharide (LPS) from Sigma- Aldrich, France.

b. Drugs: Diclofenac sodium : (100 mg/tab) (triveni chemicals; India); powdered and dissolved in $100 \mathrm{ml}$ distal water to made stock solution contain $(1 \mathrm{mg} / \mathrm{ml})$. The drug was given to the rabbit by oral rout in dose of $5 \mathrm{mg} / \mathrm{kg}$ three times daily for three days. Lippolysaccharide of E.coli, as powder (vial contain $10 \mathrm{mg}$ ) which equivalent to $(10.000 \mu \mathrm{g})$, dissolved in $(100 \mathrm{ml})$ of $0.09 \%$ normal saline to make a stock solution has concentration equal to $(100 \mu \mathrm{g} / \mathrm{kg})$.

The dose used low than that hepatotoxic dose of lippolysacchride of $(150 \mu \mathrm{glkg})$ 
c. Animals: the experiment was carried out on 24 local bred sexually mature male rabbits. The range of body weight was (1 $1.5 \mathrm{~kg}$ ), the animal were housed in special room for acclimatization. Rabbits were maintained on free access to food and drinking water. Groups of animals were divided randomly into four groups as following:

Group (1) received normal saline $(0.9 \%)$

Group (2) received diclofenac sod. (5 $\mathrm{mg} / \mathrm{kg}$ orally, three times daily for three days).

Group (3) received lipopolysaccharide $(150 \mu \mathrm{g} / \mathrm{kg}$, i.v, 24 hours before killing).

Group (4) received diclofenac sod. + Lipopolysaccharide $(5 \mathrm{mg} / \mathrm{kg}$, orally + $150 \mu \mathrm{g} / \mathrm{kg}$, i.v 24 hours before killing)

Prior to the day of experiment each rabbit was kept for more than 10 hours in restraint cage.

On the day of experiment the groups of rabbits were allocated randomly to receive either active treatment or physiological saline via pediatric stomach tube advanced through wooden clinical tongue depressor with hole in the center to control jaw movement and prevent the animal from chewing the tube (8).

After 3 days of treatment the rabbits were killed by sharp blow on the back of the

Absorbance

$$
1.49 \times 10-5
$$

Measurement of serum liver enzymes : ALT, AST): colorimetric method, hazy, to white and umber and adapted for determination of the activity in serum by Reitman (1957).(10)

L- Alanine + 2-Oxoglutarate $\leftarrow--\rightarrow$ pyruvate + L-Glutamate.

L- Aspartate +2-Oxoglutarate $<---\rightarrow$

Oxaloacetate $+\mathrm{L}-$ Glutamate.

The pyruvate or oxalate react with 2,4 DNPH to form 2, 4 dinitrophenylhydrazones, which absorbed at $505 \mathrm{~nm}$. head, the abdomen was opened and liver removed.

The concentrations of the drug used in this study represented the double therapeutic dose of the drug.

Preparation of liver homogenate and $M D$ A measurement:

A. the liver was removed and cut into small pieces then washed with cold phosphate buffer saline (PBS) and squeezed between filter paper to remove excess phosphate buffer saline.

B. five grams of the liver tissue was homogenized by electric homogenizer in $(100 \mathrm{ml})$ of cold phosphate buffer saline until large particles disappeared.

C. centrifuge at $2000 \mathrm{rpm}$ for 10 minutes and the supernatant was taken

d. $(0.1 \mathrm{ml})$ of this solution add to $(1.5 \mathrm{ml})$ of trichloroacetic acid (TCA).

E. after 10 minutes incubation at $37{ }^{\circ} \mathrm{C}$, centrifuge at $3000 \mathrm{rpm}$ for 15 minutes.

F. all the supernatant was removed and treat with $(1.5 \mathrm{ml})$ of clear solution of $0.067 \%$ thiobarbituric acid (TBA)

$\mathrm{H}$. incubated in water bath for 30 minutes at 100C.

I. absorbance was measured at $532 \mathrm{~nm}$ UV wave length.

MDA concentration was calculated using the following equation (9)

\section{the final result expressed in $\mathrm{nmol} / \mathrm{g}$}

We used colorimetric method for determination of alkaline phosphates (ALP) as in the following scheme:

Phenyl phosphate---- $\rightarrow$ phenol + phosphate Free phenol liberated by hydrolysis of substrate reacts then with $3-$ amino antipyrine in the presence of alkaline from potassium ferric cyanide to form red colored complex which absorbance measured at $510 \mathrm{~nm}$ is directly proportional to the (ALP) activity in the serum. 


\section{Statistical Analysis}

Analysis was made by using SPSS package version 15. Data were analyzed by one way ANOVA. Paired t- test was used to compare between different concentration and

\section{Results}

1. The effect of diclofenac sodium on level of MDA in the liver homogenate of the rabbit:

Diclofenac sodium increased the level of $\mathrm{M}$ $\mathrm{D} A$ in the liver homogenate at a dose of (5 $\mathrm{mg} / \mathrm{kg}$ ) by $39 \%$ as compared with control. And this effect was statistically not significant (p.0.05) table 1 .

2. Effect of L PS on level of M D A in liver homogenate of the rabbit: L P S increased the level of the $\mathrm{M} D \mathrm{~A}$ in the liver homogenate by $28 \%$ as compared with control. And this effect was statistically not significant $(p>0.05)$. TABLE1.

3. Effect of combination treatment (Diclofenac sod + lipopolysaccharide) on the level of M D A in liver homogenate of the rabbit: this combination lead to increase the level of M D A in the homogenate by 93\% as compared with control. This effect was statistically significant $\quad(\mathrm{p}<0.05)$ TABLE 2.

4. Effect of combination treatment (Diclofenac sod. + Lipopoly saccharide) on level of the (ALT) in rabbit serum: This combination treatment leads to an increase in level of the (ALT) as compared with control. And this was highly significant $(\mathrm{p}<0.01)$ and the percentage change from control was $(346 \%)$ TABLE3.

5. Effect of Diclofenac sodium on level of (ALP) in the serum of the rabbit:-

Administration of diclofenac sodium to the rabbit causes decrease in the level of (ALP )as compared with control, but this

Table $1:$ the effect of different treatment on MDA of liver tissue.

\begin{tabular}{|r|r|}
\hline Group of rabbits treated with & MDA in liver tissue (nmol/gm) \\
\hline Control group(N .S) & $0.86 \pm 0.23$ \\
\hline Treated with diclofenac sod & $1.12 \pm 0.08$ \\
\hline Treated with , lipopolysaccharide & $1.10 \pm 0.19$ \\
\hline $\begin{array}{r}\text { Treated with diclofenac sod. } \\
\text { +lipopolysaccharide }\end{array}$ & $1.66 \pm 0.44$ \\
\hline
\end{tabular}

$\neq$ Significant from diclofenac sod. alone $(\mathrm{p}>0.05)$ and the percentage change from control(-55.4\%) table 1 .

6 .Effect of the diclofenac sodium on serum level of (AST) in rabbit:

Administration of diclofenac sodium to the rabbit show an increase in (AST) level as compared with control , and this elevation was statistically $($ significant $(\mathrm{p}<0.01)$ and percentage change from control was $256 \%$ table1.

7 .effect combination treatment (diclofenac sod. + lipopolysaccharide) on serum level of (AST) in rabbit: this combination treatment causes an increase in level of (A $\mathrm{S} \mathrm{T}$ ) in the rabbit serum as compared with control. And consider as highly significant $(\mathrm{p}<0.01)$ and percentage change from control was $(884 \%)$ TABLE4

8 .effect of lipopolysaccharide on ALP in serum rabbit: when we LPS to the rabbit there was an increase in level of ALP as compared with control. But this elevation was statistically not significant $(\mathrm{p}>0.05)$ and percentage change from control $(8.5 \%)$ TABLE4

9. The effect of combination treatment (diclofenac sod. +lipopolysaccharide) on ALP level in serum rabbit: when we give this combination to the rabbit, lead to decrease in level of ALP as compared with control. And this was statistically not significant $(\mathrm{p}>0.05)$ and the percentage change from control was(-14.7\%) TABLE4 
TABLE 2: The effect of different treatment on serum ALT in liver tis sue (iu/l)

Group of treated rabbit with

\begin{tabular}{|r|r|}
\hline Control group (N.S) & $62.83 \pm 61.38 \quad(\mathrm{iu} / \mathrm{l})$ \\
\hline Diclofenac sod. & $72.16 \pm 30.26$ \\
\hline Lipopolysaccharide & $175.66 \pm 82.41$ \\
\hline $\begin{array}{r}\text { Diclofenac sod. } \\
\text { +lipopolys accharide }\end{array}$ & $281 \pm 25.25 \quad \neq$ \\
\hline
\end{tabular}

$\neq$ Significant from diclofenac sod.alone

Table 3: the effect of different treatment on serum (AST) in liver tis sue.

\begin{tabular}{|r|cr|}
\hline Control group (N.S) & $28.75 \pm 4.73$ & ( iu/l) \\
\hline Diclofenac sod. & $106.0 \pm 32.21$ & $\neq$ \\
\hline Lipopolysaccharide & $141.75 \pm 80.13$ & $\neq$ \\
\hline $\begin{array}{r}\text { Diclofenac sod. } \\
\text { +lipopolysaccharide }\end{array}$ & $281.0 \pm 53.54$ & $\neq \neq$ \\
\hline
\end{tabular}

$\neq$ Significant from control alone.

$\neq$ Significant from control alone.

$\neq$ significant from diclofenac sod, alone

Table 4: the effect of different treatment on (ALP) in serum of the rabbit.

\begin{tabular}{|r|r|}
\hline Control group (N.S) & $56.18 \pm 13.1 \quad(\mathrm{iu} / \mathrm{l})$ \\
\hline Diclofenac sod. & $23.40 \pm 8.97$ \\
\hline Lipopolysaccharide & $60.95 \pm 25.25$ \\
\hline $\begin{array}{r}\text { Diclofenac sod. }+ \\
\text { lipopolysaccharide }\end{array}$ & $47.89 \pm 18.37$ \\
\hline
\end{tabular}

\section{Discussion}

We used rabbit in the present study as a model for detecting idiosyncratic drug hepatotoxicity by using the interaction of drugs with LPS. The previous studies were conducted on rodents using either mice or rat. The rabbit is easier to handle and can easily be given by intravenous injection in the marginal ear vein. The large size of the liver also helps better handling, necked eye examination and histopathological examination.Homogenization is a disorganization stage where tissue is converted to so call homogenate (11). The aim of this process is to disrupt tissue and break open the boundaries (cell membrane) of the cell to release the cellular contents. The use of liquid rather than solid (sand or glass ) for homogenization is based on the fact that force needed one for animal cell disruption is mild. This is in contrast to bacterial or plant cells which need greater force because of presence of cell wall in these organisms that makes cell disruption more difficult.Choosing the medium in which to suspend the tissue during homogenization is also essential. Phosphate buffer saline (PBS) was selected in this study to provide the required $\mathrm{pH}$ and isotonisty as that for human body (11).Oxidative stress has been implicated list of human disease such as colonic cancer and inflammatory bowel disease (12), (13).Oxidative stress is also one characteristic finding of inflammation. Tissue undergoing chronic inflammation is at an increased risk of undergoing malignant changes. Many cancers arise from sites of infection and chronic irritation as well as inflammation and oxidative stress may be an important contributor (14). Diclofenac sodium when given alone produce statistically significant increase in AST levels, it also produced histopathological changes in 3/6.Diclofenac sodium is widely used non-steroidal antiinflammatory drug that can rarely cause severe liver injury, due to immune-allergic idiosyncratic reaction with involvement of 
leukotriene ( IL-17 and IL-1B )(15). It was also found that there is an important role of mitochondrial permeability transition in the pathogenesis of hepatocyte injury induced by diclofenac and possible contribution to human idiosyncratic hepatotoxicity (16). This hepatotoxic effect was shown to be precipitated by LPS in laboratory animals

\section{References}

1.Pirmohamed M, Brekenridge AM, Kitleringham, Park BK"Advers drug reaction", BMJ 1998; (316) (7140) ; $1295-1298$

2. Bagheri $\mathrm{H}$, Michel $\mathrm{F}$, Lapeyre -Mester $\mathrm{M}$, Lagier E, Cambus JP, Valdiguie $\mathrm{p}$, Montastrus JL. "Detection and incidence of drug induced liver injuries in hospital; a prospective analysisfrom laboratory signals. Br. J. Clinpharmacol; 2000; 50:479 -484.

3.Sgro C, Clinard F, Quazir K. Chanay H, Allard C, Guilleminet C. Lenoir C. Lemoin A, Hillon P : Incidence of drug-induced hepatic injuries " a French population-based study. Hepatology ,2002; 361: 451-455.

4.pellock JM. Felbamate in epilepsy therapeutic evaluating the risk. "DrugSaf1999;(21) 225-239.

5.Dieckhaus CM, Thompson CD, Roller SG, Mac Donald TL.'Mechanisms of idiosyncratic drug reaction: The case of felbamate. Chemibiolinteract :2002 (142): 99117.

6.Chalasani N , Fontna R J, Bonkovsky HL, Watkins $\mathrm{PB}$, Davern $\mathrm{T}$ Serrano J,Yang $\mathrm{H}$ Rochon J .'Drug induced liver injury, network (Dilin) "causes, clinical features and out come from a prospective study of drug-induced liver injury in united states: Gastroenterology: 2008-(135): 1924-1934

7. Andrade RJ, Lucena MI, Fernandez MC,Pelaez G, Pachkoria K,
(17). This is agreement with our results. The administration other drugs with diclofenac sodium (18), like lipopolysaccharide or Thiazolidinediones or rosiglitazone, show an increases in AST and no changes in MDA or liver enzymes ,It also produced mild histopathological changes in $1 / 3$ of the experimental animals 
review ; Drug Metapharmacokinet ;2006 oct. 21; (5):347-356.

17. Deng X, Luyendy K JP , Zou W, Lu J, Malle E, Ganey PE, Roth RA. "Neutrophil interaction with the hemostatic system contributes to liver injury in rats ,cotreated with lipopolysaccharide and ranitidine ; J .pharmacoExpther. 2007(3220 :852 -861.

18. Al-Ali, H.S., Ms Thesis, for college of medicine, university of Basra, 2012.

\section{الجها الألتهابي والأعراض غير المتوقعة للأدوية على سمية الكبد/ في الأرانب}

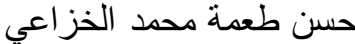

$$
\begin{aligned}
& \text { كلية الطب البيطري / جامعة البصرة }
\end{aligned}
$$

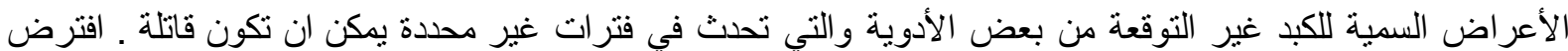

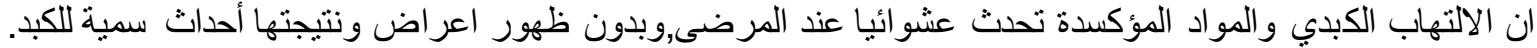

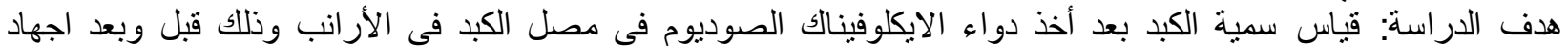
بواسطة السكريات متعددة الدهون ( LPS ) ) (LIPOPOLYSACCHARIDE ) وربط هذة مع مختلف قياسات الأجهاد,

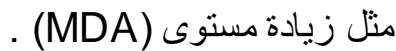
الطريقة: اربعة وعثرين ارنب محلي استخدت في هذة التجربة حيث قسمت عشوائيا الى اربعة مجاميع في كل مجموعة 6

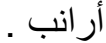
الدجموعة الأولى: أعطيت المحلول الملحي فمويا لمدة ايام التجربة.

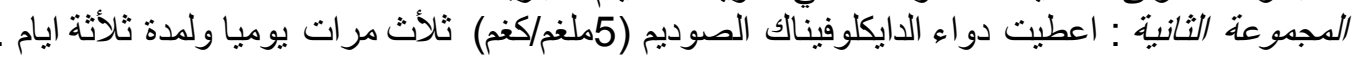

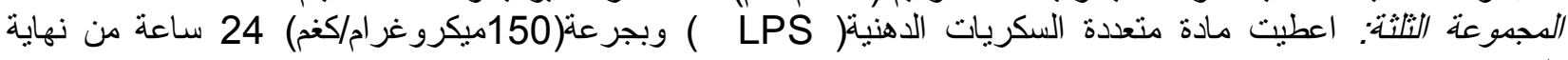

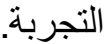

الهجموعة الرابعة: اعطيت دواء الدايكلوفيناك الصوديم اضافة الى مادة متعددت السكريات الدهنبة(5 ملغم/كغرفمويا و 150

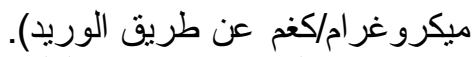
ثم في نهاية التجربة نم قياس الملوندايالديهايد( MDA ) في أنسجة الكبدو ونسبة انزيمات الكبد.

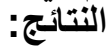

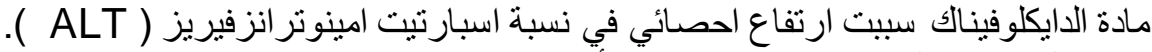

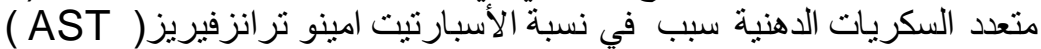

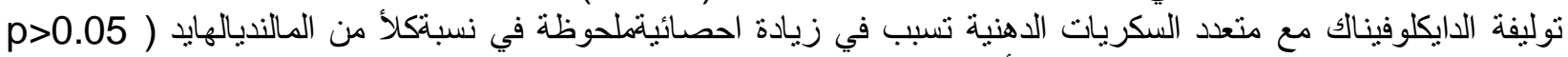

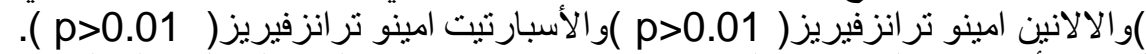

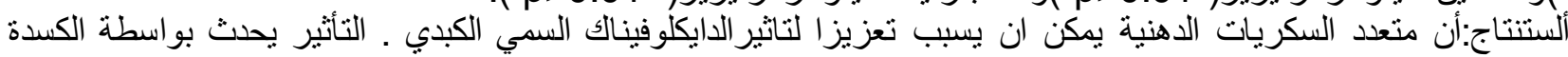

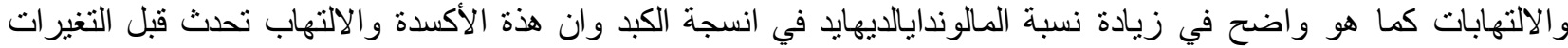
النسيجية وهذة ليس لها علاقة مع التغييلر النسيجيز . 